Library, N. W. Bidg.

AUG 191952

\title{
Fire Resistance of Shutters for Moving-Stairway Openings
}

United States Department of Commerce

National Bureau of Standards

Building Materials and Structures Report 129 


\section{BUILDING MATERIALS AND STRUCTURES REPORTS}

On request, the Superintendent of Documents, U. S. Government Printing Office, Washington $25, \mathrm{D}$. C., will place your name on a special mailing list to receive notices of new reports in this series as soon as they are issued. There will be no charge for receiving such notices.

An alternative method is to deposit with the Superintendent of Documents the sum of $\$ 5$, with the request that the reports be sent to you as soon as issued, and that the cost thereof be charged against your deposit. This will provide for the mailing of the publications without delay. You will be notified when the amount of your deposit has become exhausted.

If 100 copies or more of any report are ordered at one time, a discount of 25 percent is allowed. Send all orders and remittances to the Superintendent of Documents, U.S. Government Printing Office, Washington $25, D$. C.

The following publications in this series are available by purchase from the Superintendent of Documents at the prices indicated:

BMS2 Methods of Determining the Structural Properties of Low-Cost House Constructions.BMS3

BMS4

BMS5

BMS6

BMS8

BMS9

Suitability of Fiber Insulating Lath as a Plaster Base

Accelerated Aging of Fiber Building Boards

Plen

Structural Properties of Six Masonry Wall Constructions.

Survey of Roofing Materials in the Southeastern States

Methods of Investigation of Surface Treatment for Corrosion Protection of Steel.

Structural Properties of the Insulated Steel Construction Co.'s "Frameless-Steel" Con-

structions for Walls, Partitions, Floors, and Roofs
BMS10 Structural Properties of One of the "Keystone Beam Steel Floor" Constructions

BMS11 Structural Properties of the Curren Fabrihome Corporation's "Fabrihome" Construc-

tions for Walls and Partitions
BMS12 Structural Properties of "Steelox" Constructions for Walls, Partitions, Floors, and
Roofs Sponsored by Steel Buildings, Inc.

BMS13 Properties of Some Fiber Building Boards of Current Manufacture.

BMS14 Indentation and Recovery of Low-Cost Floor Coverings

BMS15 Structural Properties of "Wheeling Long-Span Steel Floor" Construction Sponsored by the Wheeling Corrugating Co

BMS16 Structural Properties of a "Tilecrete" Floor Construction Sponsored by Tilecrete Floors, Inc-

BMS17 Sound Insulation of Wall and Floor Constructions

Supplement to BMS17, Sound Insulation of Wall and Floor Constructions

Supplement No. 2 to BMS17, Sound Insulation of Wall and Floor Constructions

BMS18 Structural Properties of "Pre-fab" Constructions for Walls, Partitions, and Floors Sponsored by the Harnischfeger Corporation .

BMS19 Preparation and Revision of Building Codes

BMS21 Structural Properties of a Concrete-Block Cavity-Wall Construction Sponsored by the

National Concrete Masonry Association
BMS22 Structural Properties of "Dun-Ti-Stone" Wall Construction Sponsored by the Brick

BMS23 Structural Properties of a Brick Cavity-Wall Construction Sponsored by the W. Manufacturers Association of New York, Inc

BMS24 Structural Properties of a Reinforced-Brick Wall Construction and a Brick-Tile CavityWall Construction Sponsored by the Structural Clay Products Institute ...... $15 \notin$

BMS25 Structural Properties of Conventional Wood-Frame Constructions for Walls, Partitions, Floors, and Roofs

BMS26 Structural Properties of "Nelson Pre-Cast Concrete Foundation"; Wall Construction Sponsored by the Nelson Cement Stone Co., Inc...................

BMS27 Structural Properties of "Bender Steel Home" Wall Construction Sponsored by tho Bender Body Co

BMS28 Backfow Prevention in Over-Rim Water Supplies

BMS29 Survey of Roofing Materials in the Northeastern States

BMS30 Structural Properties of a Wood-Frame Wall Construction Sponsored by the Douglas

BMS31 Structural Properties of "Insulite" Wall and "Insulite" Partition Constructions

Sponsored by The Insulite Co
BMS32 Structural Properties of Two Brick-Concrete-Block Wail Constructions and a Con-
crete-Block Wall Construction Sponsored by the National Concrete Masonry Association Wall Construction Sponsored by the National Concrete Masonry

BMS33 Plastic Calking Materials

BMS34 Performance Test of Floor Coverings for Use in Low-Cost Housing: Part 1........ $10 \phi$ 16t 


\section{Fire Resistance of Shutters for Moving-Stairway Openings}

Noland D. Mitchell, Edward D. Bender, and James V. Ryan

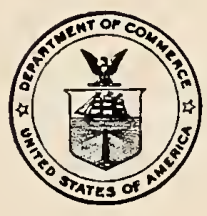

Building Materials and Structures Report 129

Issued March 1, 1952 


\section{Foreword}

This report is one of a series issued by the National Bureau of Standards, dealing with the fire resistance of building materials and constructions. It indicates the results obtained in the tests of a fire-resistant shutter for the closure of moving-stairway openings.

As moving stairways are used extensively in commercial buildings in which unprotected openings through floors might permit the passage of fire with disastrous results, the information contained in this report should be of interest to architects, the building industry, and regulatory bodies concerned with specifications or building-code requirements pertaining to moving-stairway installations.

A. V. Astin, Acting Director.

\section{Contents}

Foreword

1. Introduction

2. Construction

3. Test method and equipment

3.1. Floor-test furnace.

3.2. Temperature measurements

4. Results

4.1. Exploratory test $\ldots$

4.2. Test $\mathrm{A}$

4.3. Test $\mathrm{B}$

5. Summary and conclusions

5.1. Resistance of shutter

5.2. Effects of thermal expansion

5.3. Effectiveness of design changes made for test $B$

5.4. Passage of hot gases

5.5. General comments. 


\title{
Fire Resistance of Shutters for Moving-Stairway Openings
}

\author{
Nolan D. Mitchell, Edward W. Bender, and James V. Ryan
}

\begin{abstract}
The results of one exploratory and two full-scale fire-endurance tests on flexible rolling shutters for closing moving-stairway openings are given. The test specimens in the latter two tests included the balustrading of a normal installation. The shutters were made of galvanized steel slats moving on rollers and were of the same design in all the tests. The shutters could be operated by hand or by power drive.

The results of the fire-endurance tests indicated that the first full-scale installation design was not satisfactory because of distortions due to differential expansion of the guide rails and other structural parts. The second design, with modifications to provide for the expansion of structural parts without undue distortion, proved adequate for 3-hr fire resistance.
\end{abstract}

\section{Introduction}

Multistoried buildings have been susceptible to rapid spread of fires through unenclosed vertical openings, such as elevator and other shafts, stairwells, and chutes that have not been properly protected. Although instances of such spread of fire into several stories through moving-stairway openings have not been common, many of these openings are to be found in a class of buildings having large patronage, predominantly combustible contents, and high-value occupancy. These openings are therefore of prime interest in fire-protection considerations.

One method of protection of such openings approved by the Building Exits Code ${ }^{1}$ is set forth in the following excerpt:

Each moving stairway above the street floor (shall be protected) by an àtomatic self-closing rolling shutter which will completely enclose the top of cach moving stairway, meeting the following requirements, and of a design meeting the approval of the inspection authority having jurisdiction:

(a) The shutter shall close off the wellway opening immediately upon the automatic detection, by an approved device, of either fire or smoke in the vicinity of the moving stairway, and, in addition, there shall be provided a manual means of operating and testing the operation of the shutter.

(b) The shutter assembly shall be capable of supporting a weight of 200 pounds applied on any one square foot of area, and not less resistant to fire ol heat than 24-gage steel.

(c) The shutter shall operate at a speed of not greater than 30 feet per minute and shall be equipped with a sensitive leading edge. The leading edge shall arrest the progress of the moving shutter and cause it to retract a distance of approximately 6 inches upon the application of a force not in excess of 20 pounds applied on the surface of the leading edge. The shutter, following retraction, shall continue to closure immediately.

1 Building Exits Code, Tenth Edition, 1949, National Fire Protection Association, Boston 10, Mass.
These requircments arc in agreement with those proposed for inclusion in the current revisions of the Elevator Safety Code.

An exploratory fire test and two full-scale fire tests of rolling shutters were madc (National Bureau of Standards fire-endurance tests 242, 284, and 285 , respectively). The shutters in each of the full-scalc tests were of the same design, but the supporting frames and runways were different. These tests will be refcried to hcreinafter as "exploratory," "A," and "B," in the order in which the tests were made.

\section{Construction}

The exploratory test was made to determine the adequacy of the shutter and guides alone. Therefore, the construction of the mounting framework was relativcly simple, as shown in figure 1.

The balustrade frames used in the full-scale tests were delivered assembled by the manufacturers and required only placement in the test furnace, plastcring, and mounting of the shutters. Other details of the constructions are given in figures 2 and 3 . The major differences between the two balustrade constructions werc in mounting posts, slip joints, and other provisions added in the last installation to allow for thermal expansion of the members without undue distortion.

As previously mentioned, the shutters used in tests $A$ and $B$ were of the same design and were of sufficient strength to support $200 \mathrm{lb}$ distributed over $1 \mathrm{ft}^{2}$ at midspan. That used in the exploratory test was of essentially the same type of construction. The operating mechanism for test A included both a hand crank for manual operation and an electric motor, which drove the shutter at approximately $30 \mathrm{ft} / \mathrm{min}$. When the hand crank was swung into operating position, the electricmotor drive was automatically disconnected. 


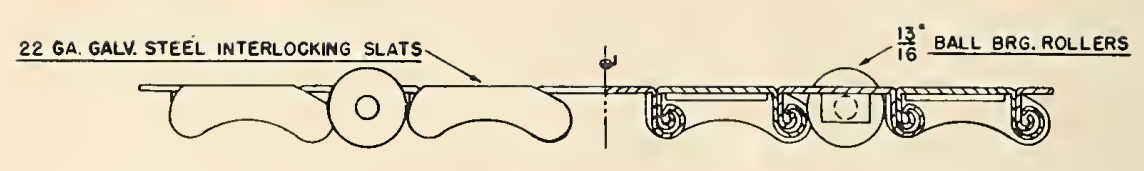

PARTIAL SECTION THROUGH SHUTTER

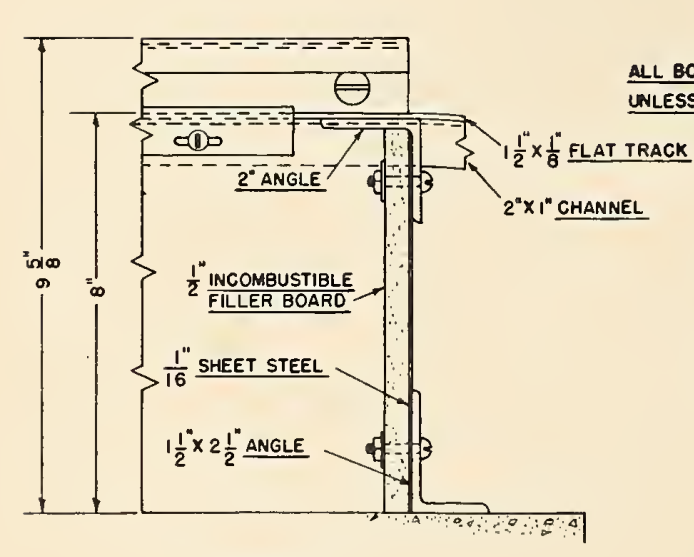

DETAIL AT B

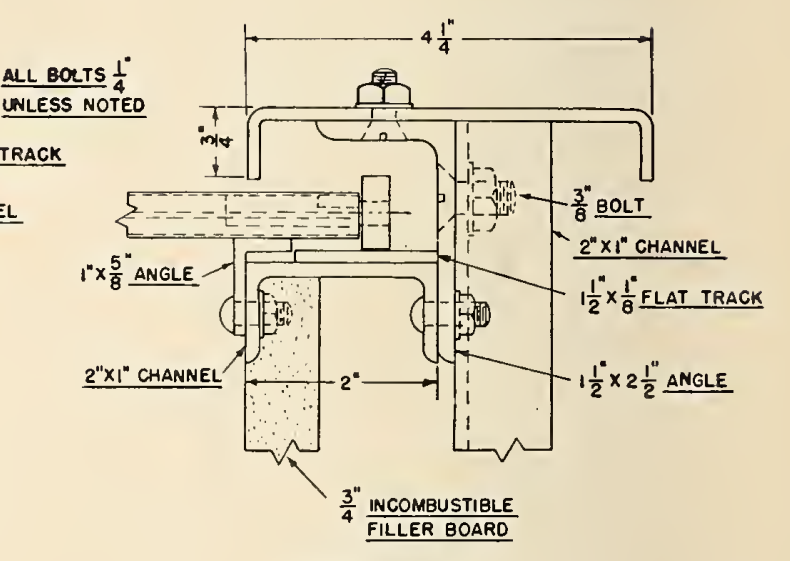

DETAIL AT A

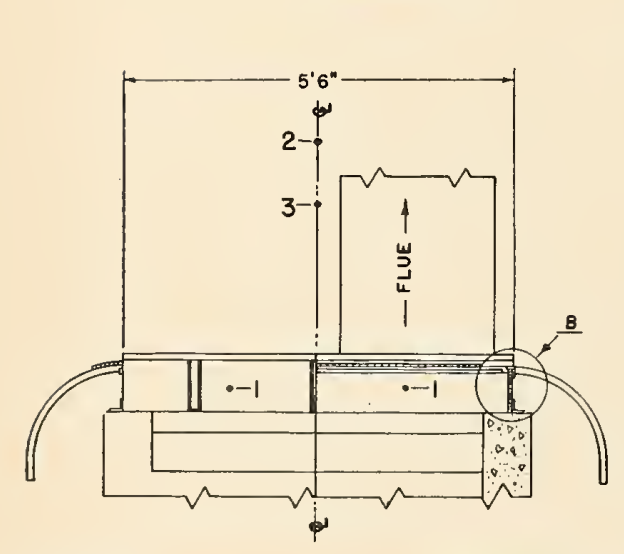

PARTIAL LONGITUDINAL SECTIONAL ELEVATION

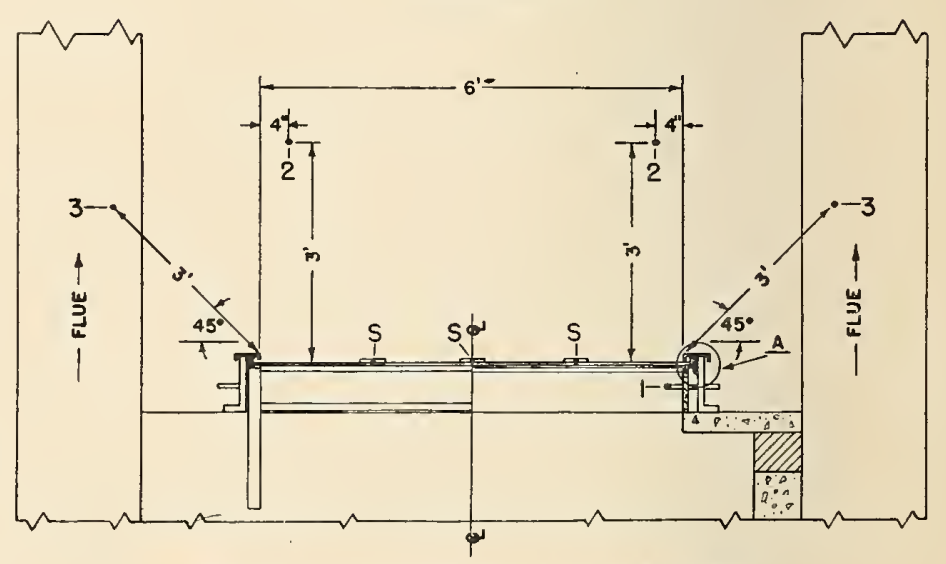

PARTIAL TRANSVERSE SECTIONAL ELEVATION

FIGURE 1. Constructions and thermocouples for exploratory test. 

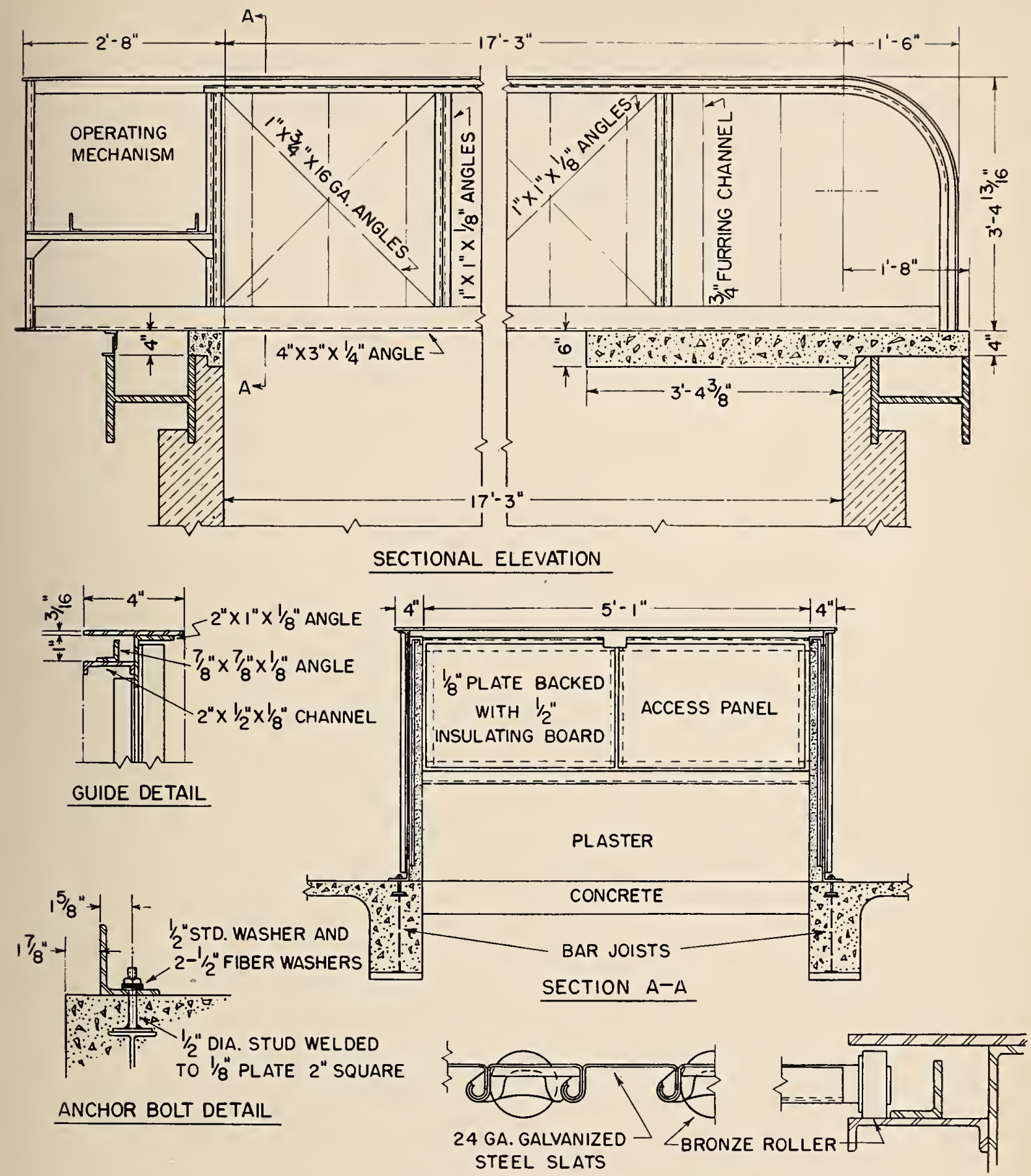

SHUTTER DETAIL

Figure 2. Construction details for test $A$. 

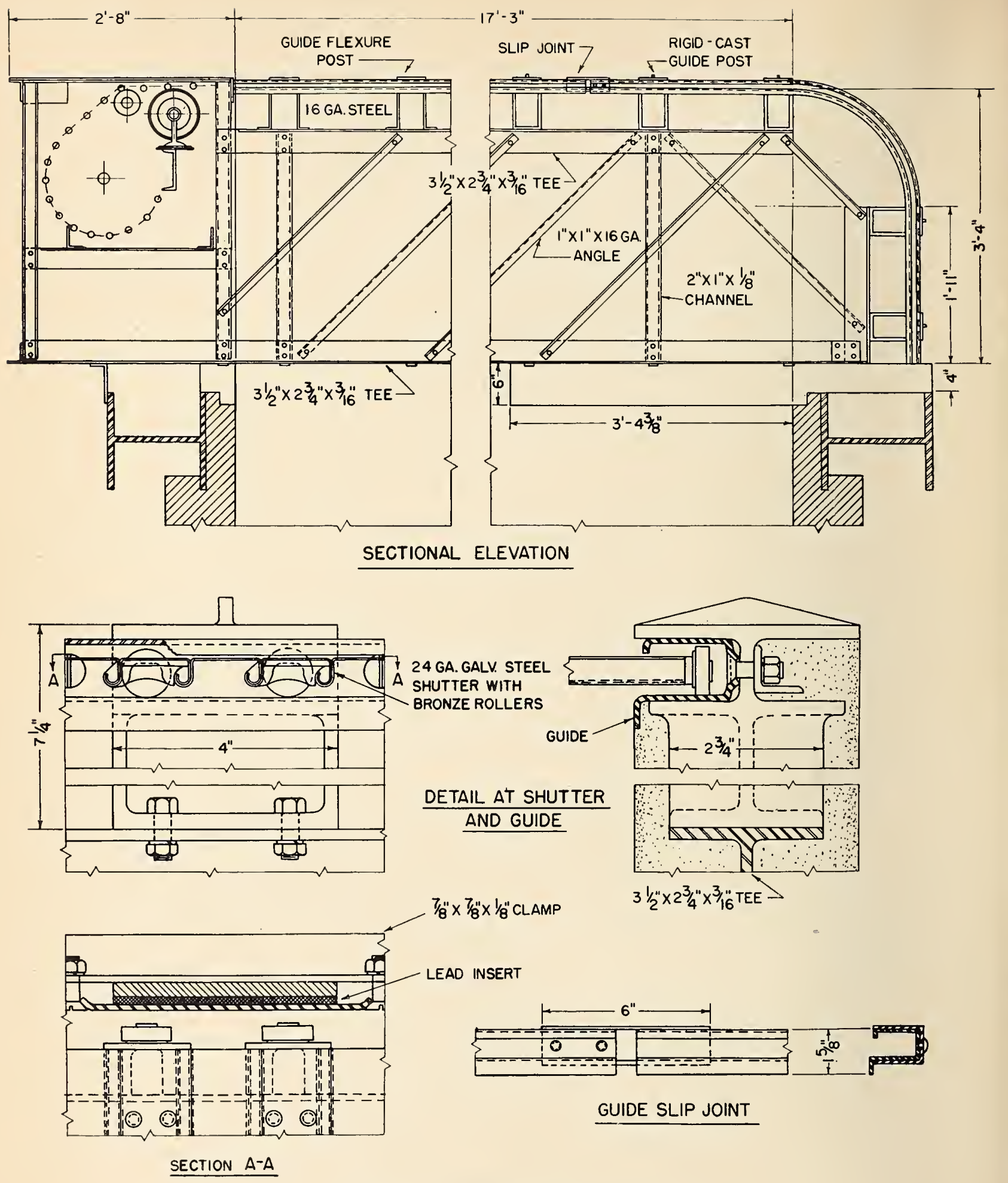

Figure 3. Construction detalls for test $B$ 


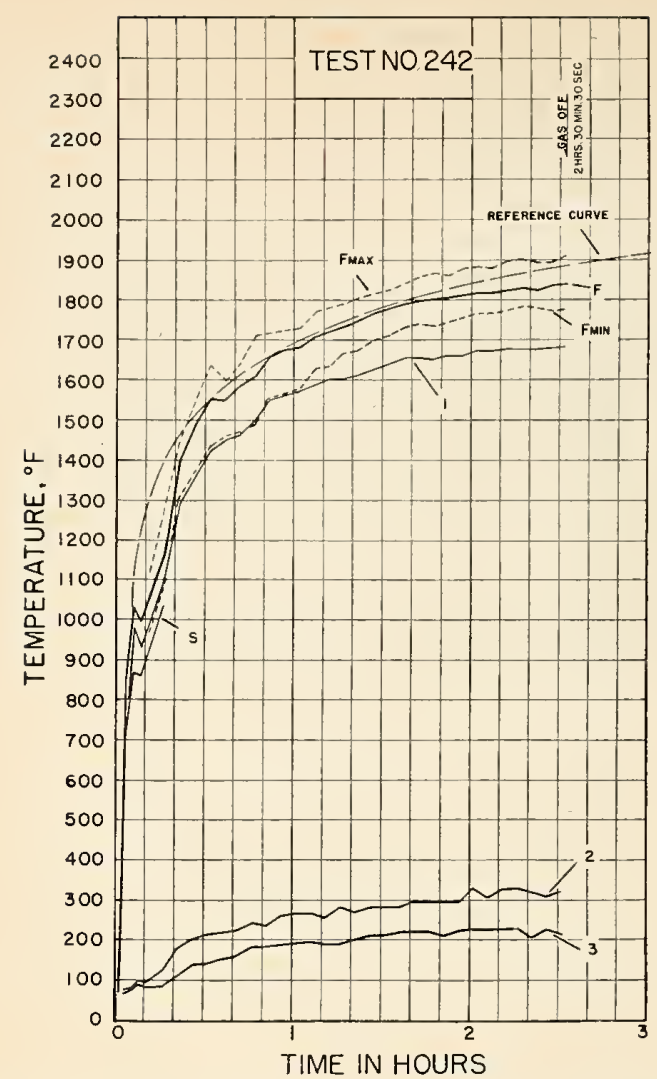

FIGURE 6. Time-temperature curves from exploratory test. The "reference curve" is the standard time-temperature curve defined in and minimum furnace temperatures, respectively. $S$ is the average of the temperatures measured on the unexposed surface of the shutter and 1,2, and 3 are the averages measured at the positions in the air outside the furnace indicated in figure 1 by the same numbers.

\subsection{Test A}

'The lubricants in the shutter' started burning and smoke was observed at $5 \mathrm{~min}$. At $7 \mathrm{~min}$ the shutter guide rails were observed to be spreading apart at the curved portion. At $20 \mathrm{~min}$ the curved portion of the rails had spread so much that the shutter rollers had come out of the guide slots. At $1 \mathrm{hr}$ the shutter was out of the slot $1 \mathrm{in}$. on one side and $1 / 2$ in. on the other. It had pulled clear of the slot for a length of $6 \mathrm{ft}$ on one edge and $3 \mathrm{ft}$ on the other and had sagged, causing the shutter to bow out beyond the front end about $6 \mathrm{in}$. The bottom chords of the balustrades had expanded over $3 / 8 \mathrm{in}$. longitudinally, notwithst anding the restraint of the floor slab. The test was ended at $3 \mathrm{hr} 1 \mathrm{~min}$, at which time a portion of the shutter had sagged 3 to $3 \frac{11}{2}$ in. at its center line, although the rollers were still held in the siderail slots. The condition of the specimen after the test is shown in figure 7 .

The severity of the fire exposure, as measured by the ratio of the area under the curve of average furnace temperatures to the area under the reference curve was 92.8 percent. These curves are shown in figure 8 . The large openings that devel-

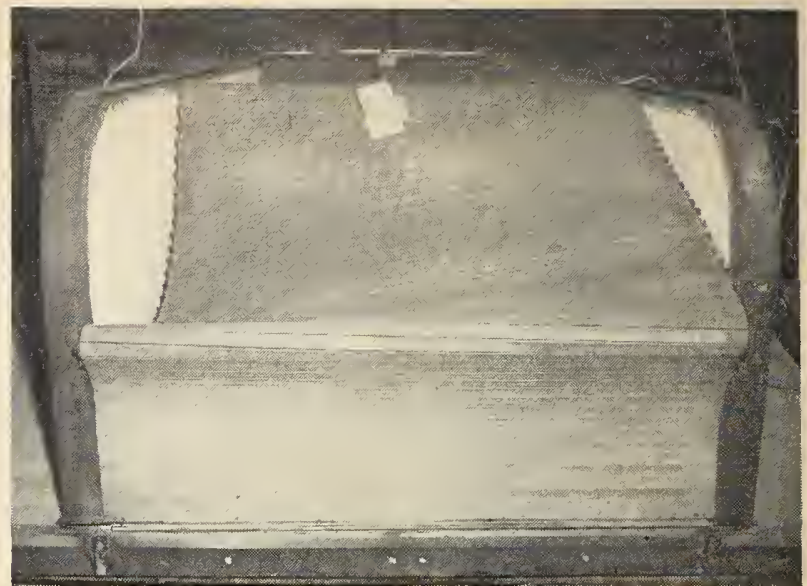

Figure 7. Shutter after test $A$.

oped bctwcen the side rails and the shutter made it difficult to keep the furnace temperatures up to those required for the standard exposure.

Following the cooling of the furnace and test specimen, the shutter surface was found to be badly oxidized under the surface thermocouple pads (fig. 9). The shutter was out of the guide rail slot for a length of 3 or $4 \mathrm{ft}$ on one edge and 12 or $14 \mathrm{ft}$ on the other (fig. 10). The electric equipment was damaged in the test to the extent that it could no longer function. The shutter could not be retracted with the hand crank. Hence it was removed by use of a cutting torch.

\subsection{Test B}

Smoke, indicating the burning of the shutter lubricants and a slight spreading of the side rails, was observed with the ends of the shutter slats showing at $3 \mathrm{~min}$. At $23 \mathrm{~min}$ the expansion joints in the shuttel guides were closed, and the shutter was sagging $1 \frac{1}{2}$ in. By $39 \mathrm{~min}$ the zinc coating on the surface of the shutter was largely oxidized, the guide rail was twisted upward slightly, and the restraining lip was bent outward. The shutter was sagging 3 in., and the base chord had expanded to push the end footing out $1 / 2$ to $1 \mathrm{in}$. The spread of the side rails at the front left a $1 / 4$-in. opening on each side between the guides and the ends of the sheet-metal slats for a length of $1 \frac{1}{2} \mathrm{ft}$. At $2 \mathrm{hr}$ the shutter was sagging $4 \mathrm{in}$., and the end footing had been puslied out and down to leave a $1 / 4-$ in. gap between the end bar of the shutter and the floor. When the test was ended at $3 \mathrm{hr} 1 \mathrm{~min}$, the shutter sag was at least 6 in., but the rollers were still in the guides, the shutter showed a dull red glow over most of its surface, and the footing had been forced out 1 to $2 \mathrm{in}$. at the front end. The severity of the fire exposure was 103 percent.

'The following day, after cooling, the shutter still sagged 4 in., but the ends of the slats were back in the guide slots (fig. 11). The unexposed surface of the shutter was coated with zinc oxide, except under the thermocouple pads where the 
oxide had blistered and flaked off. However, the steel of the shutter was in good condition. The plaster was craeked extensively but remained in place. The guide rail was deformed to the extent that four men were needed to open the shutter.

\section{Summary and Conclusions}

\subsection{Fire Resistance of Shutter}

The shutter proper withstood the fire exposure in each of the three tests. Notwithstanding the severity of test $B$, the steel slats were still strong and in fair condition, and the residual longitudinal strength of the shutter was great enough to withstand the unusually high load imposed in retracting the shutter. The load was greater than normal because of three after effects of the fire exposure: (1) the combination of shutter sag and guide deformation, which resulted in the rubbing of the guide against the ends of the shutter slats, (2) damage to the rollers by burning and loss of

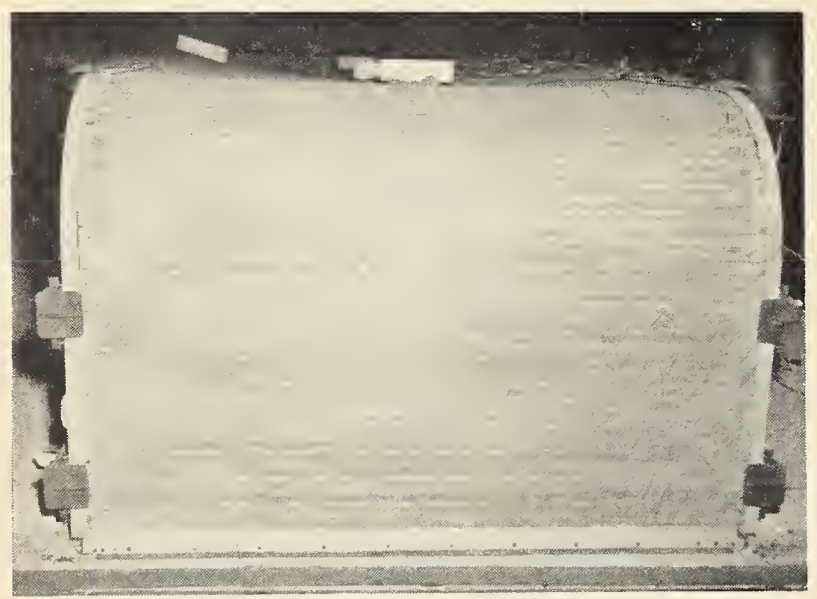

FIGURE 11. Specimen after test $B$.

their lubrication, and (3) distorting sag of the shutter, which had to be foreed out before the shutter eould be retracted through the slot into the maehine housing. These effects were to be expeeted and were not eonsidered detrimental to the overall performance of the test speeimen.

\subsection{Effects of Thermal Expansion}

In tests $A$ and $B$ the base chords of the balustrade framework expanded longitudinally and broke off a small portion of the floor slab to which it was bolted. Although this had no serious effect on either test specimen, the expansion, if more strongly resisted by the floor system of a building, might cause appreciable buckling of the framework. Continuous ehord members permit factory assembly and shipment of the assembled frame, but some provision should be made at, or before, the time of installation to allow freedom for expansion.
The primary source of trouble in test $A$ was the spreading of the side rails, or balustrades. The shutter guide rail was rigidly attached as a part of the top chord of the truss, the inner portions being directly exposed to the furnaee fire, whereas the outer portions were eooled by the air outside the furnace, a condition whieh resulted in a considerable difference in the thermal expansions along the inmer and outer edges. This difference in expansion caused bowing of the chord members and consequent spreading of the guide rail, thus allowing the shutter rollers to drop out of the guide slots. The transverse members of the housing for the operating mechanism fixed the rear ends of the guides, and outside braces set at $2 \frac{1}{2} \mathrm{ft}$ from the beginning point of curvature of the rail resulted in the spreading of the relatively free curved portion of the guides. In test B this effect was partly obviated by providing an expansion joint in the guide rail and placing the top chord of the balustrade framework below the guide rail, where it was somewhat proteeted from the fire by plaster. Another means of neutralizing unequal expansion was introduced by making saw euts in the inner edges of the top chord and the guirte rail. In spite of these provisions, some spreading of the guide rails was observed. This should be overcome by increased allowance for expansion. Any provisions that make adequate allowances for expansion effects might be substituted for those employed in test B.

The unequal thermal expansion doubtless contributed to the sag of the shutter, but this condition did not seriously affect the fire resistance.

\subsection{Effectiveness of Design Changes Made for Test B}

Plaeing the top chord of the balustrade truss $7 \mathrm{in}$. below the guide rail in test B made its protection from the fire by plaster possible and imparted some flexibility to the structure. The expansion joint in the shutter guide rail appeared to be not quite long enough. For the temperature obtained in the test, the expansion of a guide rail of the length required would be about $2 \frac{3}{4} \mathrm{in}$. The number of saw cuts in the inner edge of each top chord should be inereased to not less than one every $5 \mathrm{ft}$.

The shutters for both tests A and B were of the same design. The failure of the structure in test A could therefore be laid to the warping of the balustrade framework rather than to any defieieney of the shutter itself. It is doubtful whether the use of the bolted rather than a welded balustrade assembly in test B made any difference in the fire resistance. Either method should provide an aeeeptable structure.

\subsection{Passage of Hot Gases}

To obtain smooth operation, it was required that the edges of the shutter move freely in the guides. This necessitated at least slight openings around the edges of the shutter, through which some of the hot furnace gases escaped. 
Such an opening through a floor would not be permissible because of the combustibles that might normally be placed there. However, as combustibles should not be in contact with the shutter, nor even close to it, neither the passage of the small amount of hot gases around it nor the emission of heat from its slats was considered failure. Two thermocouples mounted $3 \mathrm{ft}$ above each of the two edges of the shutter indicated that the temperature rise at those positions would not ordinarily be hazardous.

\subsection{General Comments}

This report is intended to indicate some of the problems encountered in the design of rolling shutters for moving stairways and to establish goals to be achieved in the devclopment of satisfactory designs. Although the design of the specimen for test B (fig. 3) was satisfactory, it is not to be implied that the manner in which this was achieved was the only satisfactory one. Any design must make adequate provision for thermal expansion equal or unequal, avoid undue distortions, and must retain the necessary structural stability of the device if it is to be deemed satisfactory from a fire-protection standpoint.

Washington, December 5, 1951. 



\section{BUILDING MATERIALS AND STRUCTURES REPORTS}

[Continued fronı cover page II]

$\mathrm{BMS} 36$

BMS38

BMS39

BMS42

BMS43

BMS44

BMS47

BMS48

BMS49

BMS50

BMS51

BMS52

BMS53

BMS54

BMS55

BMS56

BMS58

BMS59

BMS60

BMS61

BMS62

BMS63

BMS64

BMS65

BMS66

BMS67

BMS68

BMS69

BMS70

BMS71

BMS72

BMS73

BMS74

BMS75

BMS76

BMS77

BMS78

BMS79

BMS80

BMS81

BMS82

BMS83

BMS84

BMS85

BMS86

BMS87

BMS89

BMS90

BMS91

BMS92

BMS93

Structural Properties of Wood-Frame Wall, Partition, Floor, and Roof Constructions With "Red Stripe" Lath Sponsored by The Weston Paper and Manufacturing Co W. E. Dunn Manufacturing Co _...........

Structural Properties of a Wall Construction of "Pfeifer Units" Sponsored by the Wisconsin Units Co . . W

Structural Properties of Wood-Frame Wall and Partition Construction with "Celotex" Insulating Boards Sponsored by The Celotex Corporation

Performance Test of Floor Coverings for Use in Low-Cost Housing: Part 2 .

Surface Treatment of Steel Prior to Painting

Structural Properties of Prefabricated Wood-Frame Constructions for Walls, Partitions, and Floors Sponsored by American Houses, Inc . . . .

Structural Properties of "Precision-Built" Frame Wall and Partition Constructions Sponsored by the Homasote Co C....

Metallic Roofing for Low-Cost House Construction

Stability of Fiber Building Boards as Determined by Âceelerated Äging

Structural Properties of "Tilecrete Type A" Floor Construction Sponsored by the Tilecrete Co

Effect of Ceiling Insulation Upon Summer Comfort

Structural Properties of a Masonry Wall Construction of "Munlock Dry Wall Brick" Sponsored by the Munlock Engineering Co _._.

Effect of Soot on the Rating of an Oil-Fired Heating Boiler

Effects of Wetting and Drying on the Permeability of Masonry Walls.....

A Survey of Humidities in Residences.........

Strength of Soft-Soldered Joints in Copper Tubing.

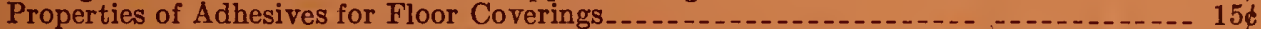

Strength, Absorption, and Resistance to Laboratory Freezing and Thawing of Building Bricks Produced in the United States.

Structural Properties of Two Nonreinforced Monolithic Concrete Wall Constructions.- $10 \phi$

Structural Properties of a Precast Joist Concrete Floor Construction Sponsored by the Portland Cement Association

Moisture Condensation in Building Walls

Solar Heating of Various Surfaces_... -

Methods of Estimating Loads in Plumbing Systems.

Plumbing Manual ..............

Structural Properties of "Mu-Steel" Prefabricated Sheet-Steel Constructions for Walls, Partitions, Floors, and Roofs, Sponsored by Herman A. Mugler ........... 15\&

Performance Test for Floor Coverings for Use in Low-Cost Housing: Part 3.-... $20 \phi$

Stability of Fiber Sheathing Boards as Determined by Accelerated Aging

Asphalt-Prepared Roll Roofings and Shingles

Fire Tests of Wood- and Metal-Framed Partitions.

Structural Properties of "Precision-Built, Jr." Prefabricated Wood-Frame Wall Construction Sponsored by the Homasote Co

Indentation Characteristics of Floor Coverings Steel Constructions for Walls, Partitions, and Roofs Sponsored by the Tennessee Coal, Iron \& Railroad Co_... Survey of Roofing Materials in the North Central States Effect of Outdoor Exposure on the Water Permeability of Masonry Walls Properties and Performance of Fiber Tile Boards Structural, Heat-Transfer, and Water-Permeability Properties of Five Earth-Wall Constructions . . .

Water-Distributing Systems for Buildings.

Performance Test of Floor Coverings for Use in Low-Cost Housing: Part 4

Field Inspectors' Check List for Building Constructions (cloth cover, 5 x $7 \frac{1}{2}$ inches) - - 306

Water Permeability of Walls Built of Masonry Units _...

Strength of Sleeve Joints in Copper Tubing Made With Various Lead-Base Solders.-- $15 \phi$

Survey of Roofing Materials in the South Central States...........................

Dimensional Changes of Floor Coverings With Changes in Relative Humidity and

Structural, Heat-Transfer, and Water-Permeability Properties of "Speedbrik" Wall Construction Sponsored by the General Shale Products Corporation

A Method for Developing Specifications for Building Construction-Report of Subcommittee on Specifications of the Central Housing Committee on Research, Design, and Construction Wood-Frame Wall Construction Sponsored by the Homasote Co............... 15 Structural Properties of "PHC" Prefabricated Wood-Frame Construction for Walls, Floors, and Roofs Sponsored by the PHC Housing Corporation...

A Glossary of Housing Terms Fire-Resistance Classifications of Building Constructions Accumulation of moisture in Walls of Frame Construction During Winter Exposure.-. 10 


\section{BUILDING MATERIALS AND STRUCTURES REPORTS}

[Continued from cover page III]

BMS94 Water Permeability and Weathering Resistance of Stucco-Faced, Gunite-Faced, and "Knap Concrete-Unit" Walls

BMS95

BMS96

BMS97

BMS98

BMS99

BMS100

BMS101

BMS102

BMS103

BMS104

BMS105

BMS106

BSM108

BMS109

BSM 110

BMS111

BMS112

BMS113

BMS114

BMS115

BMS116

BMS117

BMS118

BMS119

BMS120

BMS121

BMS122

BMS123

BMS124

BMS125

BMS126

BMS127

BMS128

BMS129

Tests of Cement-Water Paints and Other Waterproofings for Unit-Masonry Walls

Properties of a Porous Concrete of Cement and Uniform-Sized Gravel

Experimental Dry-Wall Construction With Fiber Insulating Board............. 10

Physical Properties of Terrazzo Aggregates

Structural and Heat-Transfer Properties of "Multiple Box-Girder Plywood Panels" for

Walls, Floors, and Roofs

Relative Slipperiness of Floor and Deck Surfaces

Painting and Resistance to Corrosion of Ties for Cavity Walls ...............

Mersung Steel..._._.

Measurements of Heat Losses From Slab Floors

Structural Properties of Prefabricated Plywood Lightweight Constructions for Walls,

Partitions, Floors, and Roofs Sponsored by the Douglas Fir Plywood Association -- 306

Paint Manual With Particular Reference to Federal Specifications .

Laboratory Observations of Condensation in Wall Specimens

Temperature Distribution in a Test Bungalow With Various Heating Devices

Strength of Houses: Application of Engineering Principles to Structural Design

Paints for Exterior Masonry Walls

Performance of a Coal-Fired Boiler Converted to Oil

Properties of Some Lightweight-Aggregate Concretes With and Without an Airentraining Admixture

Fire Resistance of Structural

Temperature in a Test Bungalow With Some Radiant and Jacketed Space Heaters

A Study of a Baseboard Convector Heating System in a Test Bungalow ........ 15

Preparation and Revision of Building Codes_._.

Fire Resistance of Walls of Lightweight Aggregate Concrete Masonry Units...

Stack Venting of Plumbing Fixtures.....

Wet Venting of Plumbing Fixtures

Fire Resistance of Walls of Gravel-Aggregate Concrete Masonry Units.........

Investigation of Failures of White-Coat Plasters. .

Physical Properties of Some Samples of Asbestos-Cement Siding

Fire Tests of Wood-Framed Walls and Partitions With Asbestos-Cement Facings.-.- $15 \phi$

Fire Tests of Steel Columns Protected With Siliceous Aggregate Concrete.......- $15 \phi$

Stone Exposure Test Wall

The Self-Siphonage of Fixture Traps

Effect of Aging on the Soundness of Regularly Hydrated Dolomitic Lime Putties... *

Atmospheric Exposure Tests of Nailed Sheet Metal Building Materiais.............

Fire Resistance of Shutters for Moving-Stairway Openings........

-In press. 